\title{
THE EXPLOITATION OF VULNERABILITY: DIMENSIONS OF CITIZENSHIP AND RIGHTLESSNESS IN CANADA'S SECURITY CERTIFICATE LEGISLATION
}

\section{Christiane Wilke* and Paula Willis**}

Why do policies with the stated purpose of protecting national security often exclusively target non-citizens as security threats? This article examines how prevalent ideas about security and citizenship impact on the rights of non-citizens through an analysis of the Canadian security certificate procedure and the Supreme Court's decision in Charkaoui. A multidimensional understanding of citizenship and statelessness shows that the security certificates detainees share complex vulnerabilities that remain unacknowledged in Charkaoui. Instead, Charkaoui reiterates and exploits the detainees' rightlessness by placing them outside of Canadian society and investing them with a fictional agency in choosing between detention and deportation.

Pourquoi les politiques dont le but énoncé est de protéger la sécurité nationale visent-elles souvent exclusivement les non-citoyens comme menaces à la sécurité? Cet article examine l'impact des idées courantes au sujet de la sécurité et de la citoyenneté sur les droits des non-citoyens en analysant le processus de délivrance de certificats de sécurité et l'arrêt Charkaoui de la Cour Suprême. Une compréhension multi-dimensionelle de la citoyenneté et de l'apatridie fait voir que les détenus en raison de certificats de sécurité ont en commun des vulnérabilités complexes non reconnues dans Charkaoui. Plutôt, Charkaoui réitère et exploite l'absence de droits des détenus en les situant à l'extérieur de la société canadienne et en les investissant d'une agence fictive pour choisir entre la détention et la déportation.

\section{INTRODUCTION}

That the majority on occasion must be checked when proceeding against a minority of its fellow citizens is inevitable and probably salutary; but that the majority must be checked in proceedings against hostile aliens by a judge, simply because he doesn't think deportation is a good idea, is intolerable. ${ }^{1}$

\footnotetext{
Assistant Professor, Department of Law, Carleton University [christiane_wilke@carleton.ca]. We thank Doris Buss, Daiva Stasiulis, Rueban Balasubramaniam and Sue Gemmell for comments and suggestions offered at different stages of this project that originated in Paula Willis' Honours Thesis. We also benefited from access to manuscripts by David Dyzenhaus ("Legality and Emergency - The Judiciary in a Time of Terror") and Kerri Froc ("Multidimensionality and the Matrix: How the Charter Can Better Expose Subordination").

** MPhil Candidate in Political Theory at the University of Oxford [paula.willis@politics.ox.ac.uk].

1 William Rehnquist, memorandum to Justice Jackson on Shaughnessy v. Mezei, quoted from
} 
Non-citizens are often the first to be targeted by policies that are implemented in the name of national security: they easily appear to be "hostile aliens" about whom Rehnquist complained, as noted above. How are ideas of national security translated into policies that exclusively target non-citizens as security risks? And how do courts engage with the ideas of security, foreignness and risk on which these policies are based? This article examines the Canadian Supreme Court's Charkaoui decision's engagement with the politics of belonging, foreignness, and risk. Charkaoui invalidated portions of the security certificate mechanism that facilitated the long-term detention of non-nationals deemed to pose a threat to Canadian security. ${ }^{2}$ This mechanism has parallels in the immigration legislation of other countries, notably the United Kingdom and the United States. ${ }^{3}$ Since 2004, the highest courts in these countries have reviewed and partially challenged the legal framework underpinning the detention of non-citizens. ${ }^{4}$ Some of these detentions, such as the ones complained about in Charkaoui and the British Belmarsh case, ${ }^{5}$ have no clear end in sight. These cases raise the issue of indefinite detention: the application of immigration law mandates that the "strangers" who suddenly appear threatening to the body politic are detained to be sent home, ${ }^{6}$ but they lack a home to which they can return without fear of torture or mistreatment. Indefinite detention arises at this intersection between immigration detention for the purpose of deportation and the presence of severe legal, moral or practical concerns about deportation.?

We examine the Canadian Supreme Court's Charkaoui decision on the security certificate procedure through the lens of citizenship and belonging and its opposites - statelessness and rightlessness. Our analysis of citizenship and rightlessness is based on a re-reading of Hannah Arendt's discussion of human rights in The Origins of Totalitarianism ${ }^{8}$ through the lens of recent accounts that conceptualize citizenship and subordination as multidimensional and disaggregated practices and statuses. Which understandings of security and citizenship underpin these policies and the courts' responses to them? How do the legal

Charles Weisselberg, "The Exclusion and Detention of Aliens: Lessons from the Lives of Ellen Knauff and Ignatz Mezei” (1995) 143 U.Pa.L.Rev. at 933, n. 191. The case was decided in 1953: Shaughnessy v. U.S. ex rel Mezei, 345 U.S. 206. Mezei remained excluded from the U.S. but was released on immigration parole in 1954.

2 Charkaoui v. Canada (Citizenship and Immigration), 2007 SCC 9, [2007] 1 S.C.R. 350 [Charkaoui].

3 See John Ip, "Comparative Perspectives on the Detention of Terrorism Suspects" (2007) 16 Transnat'l L, \& Contemp. Probs. at 773 [Ip, “Comparative Perspectives”]; and Thomas Poole, "Recent Developments in the 'War on Terrorism' in Canada" (2007) 7 Human Rights Law Review at 633 [Poole, "Recent Developments"]. On U.S. immigration detention in the antiterrorism context, see David Cole, Enemy Aliens, 2d ed. (New York: The New Press, 2005) at 25-27 [Cole, Enemy Aliens].

4 Rasul v. Bush, 542 U.S. 466 (2004); A (FC) v. Secretary of State for the Home Department, [2004] UKHL 56 [Secretary of State].

5 Secretary of State, supra.

6 See Zygmunt Bauman, "Strangers: The Social Construction of Universality and Particularity" (1988-1989) No. 78 Telos 7 at 9-10 [Bauman, "Strangers"].

7 See Catherine Dauvergne, "Security and Migration in the Less Brave New World" (2007) 16 Soc. \& Leg. Stud. 633 at 535 [Dauvergne, "Security and Migration"].

8 Hannah Arendt, The Origins of Totalitarianism (New York: Harcourt, Brace \& Company, 1973) at 290 [Arendt, Origins of Totalitarianism] 
challenges to such measures reconfigure the imaginations of rights, membership, and security? We argue that Charkaoui does not recognize but instead exploits the security certificate detainees' substantive rightlessness.

The security certificate process has the ostensible purpose of facilitating the speedy deportation of non-citizens deemed threats to Canadian security. As of February 2008, six persons are subject to security certificates: Mohamed Harkat, a refugee from Algeria; Hassan Almrei, a refugee from Syria; Mahmoud Jaballah and Mohammed Mahjoub, Egyptian citizens; Adil Charkaoui, a Moroccan citizen and permanent resident of Canada; and Manickavasagam Suresh, citizen of Sri Lanka. ${ }^{9}$ The cases of Harkat, Charkaoui, Mahjoub, Jaballah, and Almrei have attracted special public attention since the certificates against them coincide with the wider post-9/11 securitization of Muslim men in North America and beyond. The "Security Certificate Five" are considered to be dangerous in Canada, but the Charter and human rights instruments halts their deportation due to the risk of torture in their countries of citizenship. Four of the detainees have been released into supervised house arrest. Family members and communities have been enlisted in the control of the detainees. Hassan Almrei, who has no family in Canada, remains in detention. ${ }^{10}$ We propose to interpret this regime of detention, supervised release and threat of deportation not as a specific human rights violation. Rather, we follow Hannah Arendt in conceptualizing the detainees' situation as a denial of the more fundamental "right to have rights" or the right to be treated as a person to whom the human rights envisioned in national constitutions and international law apply as a matter of right, not of discretion or charity. ${ }^{11}$ While the detainees are not treated as non-persons without any rights whatsoever, the rights that they are granted appear as grants arising from the state's discretion and the commitment to the rule of law as procedural justice, not as rights inherent in the human status of the detainees.

In February 2007, the Charkaoui invalidated parts of the security certificate scheme but left the overall framework in place. In the media, the Charkaoui decision was hailed as "not just a ruling, [but] a statement"12 in favour of reconciling competing legal values without jeopardizing security. Some commentators praised the Court for having "found a fair and pragmatic way to resolve the moral dilemma of the age of terror." ${ }^{13}$ Yet in parliamentary committee hearings on a bill designed to render the partially invalidated legislation compatible with the Charter, a member of parliament cautioned against amendments that would grant detainees substantively more rights, remarking that " $t$ ] he Supreme Court has upheld almost the entire security certificate regime, except for the part about the special advocate." ${ }^{14}$ The complacent tone of the debate and Parliament's very

9 Sue Montgomery, "Held 21 months without charge, accused terrorist freed on bail" Ottawa Citizen (18 February 2005).

10 The term "detainees" will be used throughout the article since the conditions of supervised release constitute mere outsourcing of detention and control, not the granting of freedom.

11 See Seyla Benhabib, The Rights of Others (Cambridge: Cambridge University Press, 2004) at 56, 68 [Benhabib, The Rights of Others].

12 Kirk Makin, "A big thumbs-up for civil libertarians," Globe \& Mail (24 February 2007) A4.

13 "The court reconciles liberty and security," Editorial, Globe \& Mail (24 February 2007) A18.

14 Gord Brown (Leeds-Grenville, CPC), Standing Committee on Public Safety and National Security, 39 ${ }^{\text {th }}$ Parliament, $2^{\text {nd }}$ session, No. 005 (29 Novmber 2007). 
moderate pace and scope of reforming the security certificate mechanism hint at serious limitations of Charkaoui as far as the rights of the detainees are concerned. Here, we scrutinize the decision for its theoretical underpinnings, its language, its silences, and its limits. We ask why certain non-citizens remain extremely vulnerable to harsh security measures and show how rightlessness persists alongside a robust commitment to human rights.

In order to account for the complexities of immigration law and security rhetoric intersecting here, we use a multifaceted conception of citizenship that distinguishes formal citizenship, effective belonging, and supplementary sources of rights claims. These distinctions help to identify the specific legal vulnerabilities of the Canadian security certificate detainees. The Security Certificate Five do not hold Canadian passports and thus do not hold formal citizenship. In addition, they are seen as outside the Canadian nation whose security the government has to protect, thus lacking effective belonging. Finally, the Security Certificate Five do not have other compelling rights claims arising from their citizenships to fall back upon. In fact, their birth citizenships are sources of insecurity rather than rights. The conjunction of these conditions renders the detainees vulnerable to rightlessness understood as the inability to enjoy the status of a person with human rights protections as rights, not voluntary grants or concessions by political authorities.

Charkaoui, we argue, does not acknowledge the vulnerabilities that become visible through the lens of a multidimensional account of citizenship. Instead, Charkaoui reiterates the detainees' exclusion from Canadian society and exploits their legal and social vulnerabilities. Charkaoui adds layers of procedural rights to the security certificate process in order to bolster the rule of law as procedural justice. Yet the ruling does little to address the underlying substantive rightlessness of those who are subject to security certificates. The detainees are still primarily seen as threats, not bearers of rights. Indeed, the additional procedural rights appear as a "veneer of legality" ${ }^{15}$ masking and legitimating the exploitation of a more fundamental rightlessness. Charkaoui thereby raises the question of the relationship between the rule of law and the rights of marginalized people: can the rule of law empower those who are subject to the discretionary practice of immigration law, or does it become "a formalistic ideology deployed in support of national sovereignty" 16 in the context of immigration law?

We proceed by providing a brief overview and critical analysis of the security certificate process (II). We continue with a conceptual discussion of different dimensions of citizenship and rightlessness, drawing upon Hannah Arendt's account of the fragility of human rights (III). The third part of the article shows how Charkaoui engages with the detainees' specific vulnerabilities that stem from their lack of citizenship and belonging (IV).

\section{DISPLACING INSECURITY: SECURITY CERTIFICATES IN CANADA}

Security certificates are used when information surfaces indicating that a per-

15 The expression is used in a parallel British case: Re MB, [2006] EWCH 1000 (Admin) at para. $103[\operatorname{Re} M B]$.

16 Dauvergne, "Security and Migration" supra note 7 at 546. 
son who is lawfully present in Canada might nevertheless be "inadmissible". Inadmissibility on security grounds is stipulated in section 34 of the Immigration and Refugee Protection Act (2002) [IRPA] as follows:

(1) A permanent resident or a foreign national is inadmissible on security grounds for:

(a) engaging in an act of espionage or an act of subversion against a democratic government, institution or process as they are understood in Canada;

(b) engaging in or instigating the subversion by force of any government;

(c) engaging in terrorism;

(d) being a danger to the security of Canada;

(e) engaging in acts of violence that would or might endanger the lives or safety of persons in Canada; or

(f) being a member of an organization that there are reasonable grounds to believe engages, has engaged or will engage in acts referred to in paragraph (a), (b) or (c).

Security certificates are issued by the Minister of Citizenship and Immigration and the Minister of Public Safety on the advice of the Canadian Security Intelligence Service [CSIS]. Upon the signature by the ministers, the certificate is automatically referred to a designated Federal Court judge who has to assess the "reasonableness" of the certificate. ${ }^{17}$ The reasonableness test asks the Federal Court judge to decide whether there are "reasonable grounds to believe" that the evidence presented by the government establishes inadmissibility on security grounds. The designated judge merely needs "a bona fide belief in a serious possibility based on credible evidence," which is "more than a flimsy suspicion, but less than the civil test of balance of probabilities." ${ }^{18}$ The threshold is much lower than the standard of proof beyond reasonable doubt required by criminal law.

Since 1991, twenty-eight security certificates have been issued, twenty of which were upheld. ${ }^{19}$ Membership in a terrorist organization ${ }^{20}$ has been the most common reason for the issuance of a security certificate. Yet, three suspected

17 See Smith v. Canada (MEI) (1991), 42 F.T.R. 81, [1991] F.C.J. No. 212 (T.D).

18 Chiau v. Canada (Minister of Citizenship and Imigration), [1998] 2 F.C. 642.

19 "Security Certificates and Secret Evidence," CBC News (23 February 2007) online: CBC News in Depth <www.cbc.ca/news/background/cdnsecurity/securitycertificates_secretevidence.html> (date accessed: 14 September 2007).

20 These organizations have included the Palestinian Liberation Organization, Egyptian Islamist group Al-Jihad, Babbar Khalsa International, the Kurdistan Worker's Party (PKK), and the Liberation Tigers of Tamil Eelam. 
spies from Russia and two members of Yasser Arafat's secret security force were also deported under certificates. ${ }^{21}$ Of the twenty-eight certificates, five have named women. The current detainees have been subject to detention or subject to supervised house arrest since 2000, 2001, 2002, and 2003, respectively. They have been held on certificates for much longer than had been the custom prior to $9 / 11$ : in twelve out of the fifteen pre-9/11 cases, the persons named in the certificate were deported (occasionally to a third state) within two years; the large majority of them within one year. Security certificates were designed to speed up the deportation of non-citizens who are inadmissible on security grounds, and they largely accomplished this goal prior to $9 / 11$. In current practice, however, they facilitate indefinite detention instead of speedy removal. This shift in the practical application of pre-existing rules poses new moral and legal questions.

Under the old IRPA security certificate process, the Minister of Citizenship and Immigration may present ex parte evidence to the Federal Court judge in camera (in secret) if the disclosure of evidence to the individual, their legal counsel or the general public could jeopardize national security or the safety of any person. The designated judge reviews the file prepared by CSIS which may include evidence that would be inadmissible in criminal proceedings. ${ }^{22}$ The judge provides a summary of the evidence to the individual named under a certificate to the extent that the information may be disclosed. Additionally, IRPA guarantees the 'opportunity to be heard' for the individual named to respond to the summary of evidence. Depending on the nature of such a summary, individuals named in a security certificate might be unaware of the evidence presented against them and thus in no position to counter it. This procedure has gained the IRPA security certificate process the nickname "secret trials" and caused considerable uneasiness for participants in the process, including some of the "designated judges". ${ }^{23}$ The Charkaoui decision has invalidated this part of the IRPA as a violation of the "fundamental justice" guarantee contained in section 7 of the Canadian Charter of Rights and Freedoms, ${ }^{24}$ but has suspended the effect of the invalidation until February 23, 2008. Parliament is tasked with devising a new procedure that gives more weight to the detainees' right to see and meet the case against them, and that provides for an "independent agent at the stage of judicial review" 25 to enable limited advocacy on behalf of the detainees. Drafts and committee deliberations indicate that Parliament intends to introduce the British special advocate system without, however, giving much weight to the criticisms of this system voiced by special advocates, British courts, and analysts.

How does the security certificate process facilitate potentially indefinite detention? The practical effects of the security certificate scheme result from the interaction between legislative framework, administrative practice, and

21 "Twenty Seven Security Certificates So Far" online: Justice for Mohamed Harkat <www.zerra. net/freemohamed/twenty_seven.php> (date accessed: 20 November 2005).

22 Matthew Behrens. Submission to Subcommittee on Public Safety and National Security of the Standing Committee on Justice, Human Rights, Public Safety and Emergency Preparedness, No. 21 (21 September 2005).

23 See discussion in Charkaoui, supra note 2 at para. 50.

24 Ibid. at para. 3.

25 Ibid. 
political context. First, all non-residents and most permanent residents who are subject to a security certificate are detained. The detention review process before Charkaoui varied depending on a person's residence status in Canada: if the individual named under the certificate is a permanent resident of Canada, she is entitled to a review of her case every six months until the certificate is either found reasonable or quashed. At each review, the person named in the certificate has the opportunity to present new evidence concerning the threat they pose to Canadian society. Under the old framework, non-resident foreign nationals were only entitled to a review 120 days after the certificate has been found reasonable. In Charkaoui, the Supreme Court found this disparity of procedural rights according to immigration status unjustifiable and mandated that all persons subject to security certificates should have equal access to judicial review of the reasonableness of their detention. ${ }^{26}$ Second, if a security certificate is upheld, the ruling immediately becomes a deportation order that is not subject to appeal. The final recourse is a Pre-Removal Risk Assessment [PRRA] which, if successful, classifies the individual as a "person in need of protection" and disallows deportation to the individual's country of origin ${ }^{27}$. This can be the case, for example, if the detainee would be at risk of torture in their country of citizenship. Under the Convention against Torture, states are not allowed to "expel, return ('refouler') or extradite a person to another State where there are substantial grounds for believing that he would be in danger of being subjected to torture." ${ }^{28}$ Since deportation is the only option envisioned in the security certificate mechanism for individuals deemed 'dangerous', but is disallowed by a different body of law, those caught between the regimes of security and immigration law and human rights are subsequently left in detention with no specific endpoint in sight.

This dilemma is exacerbated by a peculiarity in the Canadian Supreme Court jurisprudence on deportation and the risk of torture. While the European Court of Human Rights considers the prohibition on deportation to torture to be absolute, ${ }^{29}$ the Canadian Supreme Court opened a fateful gap in the guarantee of non-refoulement. In Suresh, ${ }^{30}$ the Court did not use the Convention against Torture but the Canadian Charter as the standard for deciding on whether a person found inadmissible to Canada under the security certificate procedure could ever be returned to a country in which they face torture. Unlike the Convention, the Charter permits balancing rights against other legal goods. Judging in the wake of the 9/11 attacks, the Court decided "to balance Canada's interest in combating terrorism and the Convention refugee's interest in not being deported to torture, ${ }^{31}$ and found that "to deport a refugee to face a substantial risk of torture

26 Ibid. at para. 93.

27 Immigration and Refugee Protection Act (2002), s. 97.

28 Convention against Torture and Other Cruel, Inhuman or Degrading Treatment or Punishment (1984), Art. 3 (1).

29 Chahal v. U.K., (22414/93), [1996] ECHR 54 [Chahal].

30 Suresh v. Canada (Minister of Citizenship and Immigration) [2002] 1 S.C.R. 3; 2002 SCC 1, online: Supreme Court of Canada <http://scc.lexum.umontreal.ca/en/2002/2002scc1/2002scc1. html> [Suresh $]$.

31 Ibid. at para. 47. 
would generally" - but not always - violate the Charter. ${ }^{32}$ While affirming core liberal values, Suresh leaves room for unspecified "exceptional cases": "torture is so abhorrent that it will almost always be disproportionate to interests on the other side of the balance, even security interests." ${ }^{33}$

What does Suresh mean for persons named in security certificates? On the one hand, Suresh confirms that persons would generally not be deported if they might face torture. Thus, speedy deportation to states known to engage in torture becomes unlikely. On the other hand, Suresh establishes a lingering possibility that someone may be deported in spite of the risk of torture. Deportation might not be more than a theoretical possibility, but it still remains a possibility. As a consequence, the detention and supervised house arrest of those named in security certificates can still be construed as being connected to the certificate's designated purpose of facilitating deportation. The remote possibility of deportation despite the risk of torture establishes that the detainees are not conclusively non-deportable and has provided the legal justification for Canadian immigration law's continuous grip on them.

The interplay between threat determination and the limited commitment to non-deportation can be observed in the case of Mahmoud Jaballah. He was first detained on a security certificate on 31 March, 1999. This certificate was quashed by a Federal Court in November 1999. In August 2001, Jaballah was arrested on a second security certificate, which was found to be reasonable in October 2006. ${ }^{34}$ The Federal Court that confirmed the certificate also accepted that "if he [Jaballah] were to be removed to Egypt there is serious risk that he would face torture, death or inhumane treatment." ${ }^{35}$ No argument was made that Jaballah would be one of the "exceptional cases" envisioned by Suresh. The Court found that Jaballah's "continuing presence in Canada, without restraints, would constitute a danger to the security of the country." ${ }^{36}$ Still, the government may not "remove him to any country where and when there is a substantial risk that he would face torture, death, or cruel and unusual treatment." ${ }^{37}$ Thus, Jaballah can neither be free in Canada nor be deported to Egypt, leaving continued detention as the "fallback" option. Yet the detainees experience detention not only as a reprieve from deportation, but also as a violation of their rights in and of itself.

In February 2007, Charkaoui explicitly encouraged Federal Courts to consider supervised release as a less onerous alternative to detention. In April 2007, a Federal Court judge was asked to decide whether Jaballah could be released on conditions. This decision upheld the fiction encouraged by Suresh that deportation was still considered a possibility: "while Mr. Jaballah's case is borderline, there is nothing before me to suggest that the Ministers have abandoned the intention to deport him." ${ }^{38}$ The government's mere intention - even in the absence

32 Ibid. at para. 5, emphasis added.

33 Ibid. at para 76.

34 Jaballah (Re), [2006] F.C.J. No. 1706, 2006 FC 1230 [Jaballah (Re)].

35 Ibid. at para. 73.

36 Ibid. at para. 82.

37 Ibid. at para. 87.

38 Jaballah v. Canada (Minister of Citizenship and Immigration), [2007] F.C.J. No. 518, 2007 FC 379 at para. 31 [Jaballah] 
of reasonable prospects of success - to deport Jaballah is construed as sufficient for connecting restrictions on his liberties to the goal of deportation. Ultimately, Jaballah is subjected to a regime of supervised house arrest in which his family members act as "sureties" and wardens who guarantee that he will not engage in non-approved communication and activities. ${ }^{39}$ Like the detention, the house arrest relies on the fiction that the government is still trying to deport the person named in a security certificate. Were this not the case, suggested Charkaoui, the restrictions on liberty would be unconstitutional because they would be unrelated to immigration matters. The detainee's dangerousness alone can not be a valid reason for detention, especially if only non-citizens are subject to the scheme. This was the judgment of the British House of Lords in the Belmarsh ${ }^{40}$ case. In Canada, then, the "Suresh exception" makes all the difference: the theoretical possibility of deportation despite the risk of torture activates a legal regime of indefinite detention and control that is exclusively aimed at non-citizens.

We now turn from the overview of the security certificate scheme to a contextual analysis of the social and legal vulnerabilities of the security certificate detainees that helps to see why certain people are more likely to be caught in a limbo between detention, supervised house arrest, and the threat of deportation to torture. The security certificate detainees belong to a population that is vulnerable along several axes: they are perceived as culturally foreign and even threatening to the country, they do not hold Canadian passports, and they have few other sources of rights and protection available to them. The confluence of these conditions fixes the specific status of these detainees in a particular zone of rightlessness. Attention to the multiple axes of rights and membership claims helps us to position the detainees in relationship to, for example, Canadian citizens who were caught in the web of Canadian or U.S. anti-terrorism policies.

\section{VARIETIES OF CITIZENSHIP AND ZONES OF RIGHTLESSNESS}

Anti-terrorism policies in Canada, the UK, and the U.S. do not have uniform effects on individuals: non-citizens, persons with dual citizenship in certain countries, Muslims and ethnic minorities are most affected by increased surveillance, preventive detention, extraordinary rendition, and similar policies. Citizenship has been marshalled as an explanation for such vulnerabilities: noncitizens are more easily seen as carriers of violence, they are subject to the harsher regime of immigration law, and they cannot challenge their treatment by participating in elections and lobbying elected officials. ${ }^{41}$ Citizenship is often portrayed as a guarantor of rights, for example in Hannah Arendt's account of the end of human rights in The Origins of Totalitarianism. Here, we follow Arendt insofar as we recognize citizenship as a key source of rights in the context of anti-terrorism policies. Yet we revisit Arendt's analysis of citizenship and rightlessness to allow for more nuances and dimensions within the concept of citizenship.

Arendt claims that human rights are tied to effective citizenship. The most

39 Ibid. at para. 77.

40 Secretary of State, supra note 4.

41 See Cole, Enemy Aliens, supra note 3. 
fundamental right, the "right to have rights," is to belong to a political community "willing and able to guarantee any rights whatsoever." ${ }^{\text {"42 }} \mathrm{A}$ political community, in turn, primarily realizes and protects the rights of its members. The deprivation of the "right to have rights" constitutes rightlessness. It cuts much deeper than the denial of any specific human right. Rightlessness highlights the dangers of not belonging: "the moment human beings lacked their own government and had to fall back upon their minimum rights, no authority was left to protect them and no institution was willing to guarantee them." ${ }^{43}$ Instead of being deprived of particular rights, people who are rightless find themselves cast "out of legality altogether." ${ }^{\text {"44 }}$ Following conceptualizations of citizenship as disaggregated and multidimensional ${ }^{45}$ while building upon Arendt's account of rightlessness, we distinguish three dimensions of membership that can account for the differential treatment of different groups of people subject to anti-terrorism policies in the cases considered here.

Although many people who are subject to detention and house arrest under the anti-terrorism schemes are indeed not citizens of the countries in which they reside or are held, the formal citizenship represented by a passport is no insurance against getting caught in the transnational web of anti-terrorism policies. For example, the Canadian government was long unconcerned about the fate of Canadian citizen Maher Arar who had been "rendered" to Syria by U.S. authorities to be tortured. Arar holds not only a Canadian but also a Syrian passport. Dual citizenship, far from bestowing dual privileges, can undermine the assumptions of effective belonging that are usually associated with holding a country's passport. ${ }^{46}$ Arar's dual citizenship highlights one context in which the Canadian passport does not offer the needed protection. Yet other Canadians who do not hold dual citizenship also complain about Canada's lack of interest in protecting their rights: Omar Khadr has been detained in Guantánamo Bay since he was 15 years of age. The Khadr family has experienced extreme levels of hostility from the Canadian public; and the government has long refused to make motions on Omar Khadr's behalf. ${ }^{47}$ Khadr's citizenship has not provided much legal or rhetorical traction; Omar Khadr is treated as if he in fact does not belong to Canada. His "foreignness exceeds [his] citizenship." ${ }^{48}$ Khadr's case shows that not only dual citizenship but also cultural "foreignness" can undermine the degree of protection that a passport holder can normally expect.

42 Arendt, Origins of Totalitarianism, supra note 8 at 297.

43 Ibid. at 292.

44 Ibid. at 294.

45 Stephen Castles, "Nation and Empire: Hierarchies of Citizenship in the New Global Order" (2005) 42 International Politics 203 [Castles, "Hierarchies of Citizenship"], Benhabib, The Rights of Others, supra note 11; Audrey Macklin, "Exile on Main Street: Popular Discourses and Legal Manoeuvres around Citizenship" in Law Commission of Canada, ed., Law and Citizenship (Vancouver \& Toronto: UBC Press, 2006) 22 [Macklin, "Exile on Main Street"]; Audrey Macklin, "Who Is the Citizen's Other? Considering the Heft of Citizenship" (2007) 8 Theor. Inq. L. 333 [Macklin, "The Heft of Citizenship”], Daiva Stasiulis and Darryl Ross, "Security, Flexible Sovereignty, and the Perils of Multiple Citizenship" (2006) 10 Citizenship Studies 329 [Stasiulis \& Ross, "Flexible Sovereignty"].

46 See Stasiulis \& Ross, "Flexible Sovereignty" supra note 45.

47 See Macklin, "Exile on Main Street" supra note 45 at 42-43.

48 Ibid. at 29. 
These examples suffice to suggest that the practice of citizenship - Canadian citizenship, at least - is not monolithic. Rather, Canadian citizenship or its absence can be broken down into at least three dimensions that make a difference to how persons who become suspect of terrorism connections are treated. First, there is a dimension of citizenship understood as "effective belonging," a "substantive citizenship" determining the package of rights and social practices "that constitute the individual as an active, participatory, and functional political subject" ${ }^{49}$ within Canada. The Khadr family is not seen as effectively belonging to Canada; and Maher Arar's "substantive citizenship" was only reinstated after he was officially cleared of terrorism suspicions. ${ }^{50}$

Hannah Arendt's analysis of citizenship is not confined to matters of formal citizenship; it also illuminates the importance of 'effective belonging'. For Arendt, states are important because they are political communities. Nation-states offer a "social texture" in which persons "established for themselves a distinct place in the world." ${ }^{51}$ For Arendt, rights can only be realized through political action and interaction. She therefore looks for a specific "community willing and able to guarantee" 52 rights. This political community, in turn, is constituted by members whose collaboration turns the abstract shell of the state into "a place in the world which makes opinions significant and actions effective." ${ }^{53}$ Rights can only be guaranteed through political processes; and these processes are nurtured by an active citizenry. Citizens guarantee rights for those whom they recognize as fellow citizens. In this logic, the protection of the "rights of others" 54 outside of the political community arises out of principles of charity, not from a mutually shared perception of effective belonging. If rights can only be guaranteed by political communities that are constituted through ongoing political action, we should expect that the substantive citizenship that constitutes membership in this political community does not always coincide with the formal citizenship of the country's passport holders. The fates of Maher Arar and Omar Khadr, among others, point to this gap between substantive and formal membership in Canada.

Second, "formal citizenship" or "passport citizenship" refers to those who hold a country's passport. ${ }^{55}$ Formal citizenship delineates a person's legal relationship to a state and forms the basis for a package of entitlements and expectations of protection. These expectations might remain unfulfilled, as in the cases of persons who are seen to lack "substantive citizenship" and treated with less concern and respect than other passport holders. Yet in many countries including Canada, formal citizenship establishes a set of minimum entitlements - for example, the right to vote in national elections as well as the right to enter and remain in the country - that persons who do not hold formal citizenship cannot claim.

Third, the quality of one's citizenship (or lack thereof) is shaped by member-

49 Ibid. at 23.

50 Ibid. at 48.

51 Arendt, Origins of Totalitarianism, supra note 8 at 293

52 Ibid. at 297.

53 Ibid. at 296.

54 Benhabib, The Rights of Others, supra note 11.

55 Macklin, "The Heft of Citizenship" supra note 45 at 334. 
ship and rights claims in other jurisdictions ${ }^{56}$ Most people are citizens of at least one state, but many of these citizenships do not offer effective protection as some states renounce or persecute some of their citizens. Hannah Arendt estimated in 1951 that the ten million de facto stateless persons of her time - those who held passports but did not effectively belong to the political community that issued these passports - would easily outnumber the one million de jure stateless persons who do not hold passports at all. ${ }^{57}$ Moreover, the quality of one's citizenship transcends borders. As Arendt noted, "treaties of reciprocity and international agreements have woven a web around the earth that makes it possible for the citizen of every country to take his legal status with him." 58 Some passports imply promises of protection beyond state borders, while other passports shown at certain borders are more likely to raise suspicions about their bearers and their motives. ${ }^{59}$ Someone holding a Canadian passport, for example, might find that her citizenship in another country still shapes her legal and social position: she can be seen as a model of desirable transnationalism, or alternatively as an unreliable and not fully committed citizen or a potential carrier of the "bad transnationalism" of ideological fanaticism. For Maher Arar, for example, dual citizenship was decisive, but not to his advantage: instead, his Syrian citizenship gave currency to the cynical claim that he was merely sent "home" to Syria. For those who are not citizens of the country they live in, the quality of their rights claims also depends on the passports they hold: depending on their country of citizenship, they might either have recourse to effective diplomatic protection, or fear to return "home", and/or be subject to extensive scrutiny during international travel. The quality of non-citizens' rights and membership claims in one country depends, among other things, on the quality and effectiveness of their citizenship elsewhere.

International human rights can offer another source of rights claims outside of one's state of residence. In the UK, the gap between the treatment of citizens and non-citizens in the context of anti-terrorism policies has been largely closed through the invocation of the European Convention on Human Rights as binding law. ${ }^{60}$ While human rights do not establish a layer of meaningful world citizenship or "sphere ... above the nations," as Arendt warned, ${ }^{61}$ they should be taken into account in analyzing the shape of rights claims in contemporary societies.

If citizenship is a form of membership that gives access to rights and privileges, the lack of citizenship - statelessness - results in rightlessness. This was the conclusion that Hannah Arendt drew from the collapse of the interwar system of nation-states in Europe. ${ }^{62}$ Yet if citizenship and statelessness are, as Audrey Macklin

56 See Stasiulis \& Ross, "Flexible Sovereignty," supra note 45, and Macklin, "The Heft of Citizenship," supra note 45 at 355-356.

57 Arendt, Origins of Totalitarianism, supra note 8 at 279

58 Ibid. at 294.

59 Castles, "Hierarchies of Citizenship," supra note 45.

60 See Secretary of State, supra note 4.

61 Arendt, The Origins of Totalitarianism, supra note 8 at 298.

62 Ibid. at 290-302. 
suggests, end points on a continuum rather than either/or propositions, ${ }^{63}$ we should pay more attention to the multifaceted combinations between different forms and degrees of citizenship and their effects on rights claims. The "substance of citizenship" or its absence as experienced by individuals can be understood as a "composite of the elements of membership within and between all states to which the individual is connected." ${ }^{64}$ Rightlessness, statelessness, and effective citizenship are used here to indicate extreme points in a complicated landscape of rights and membership and to distinguish different qualities of citizenship as well as forms of rightlessness.

\section{CHARKAOUI: DEALING IN RIGHTLESSNESS}

The security certificate detainees largely lack the three dimensions of citizenship that would enable their rights claims to resonate with the Canadian public and the legal system. They are mostly perceived as foreign and threatening, outside of the realm of effective belonging. They are not Canadian citizens and therefore outside of the realm of full legal protection under Canadian laws. And they cannot rely on the protection of their countries of citizenship for any other rights claims. To the contrary, their formal citizenship becomes a liability because it raises the threat of deportation to torture. How does Charkaoui deal with these vulnerabilities? In the remainder of this article, we show that the Charkaoui ruling exploits each of these sources of rightlessness without fully acknowledging their effects on the status and experiences of the detainees. In short, Charkaoui presumes that the detainees effectively do not belong to the Canadian demos, it stresses the privileges of formal citizenship in order to counter allegations of discrimination against non-citizens, and it fails to recognize the detainees' lack of options for exit due to their lack of effective citizenship elsewhere.

\section{A. Our Security, Their Insecurity: Effective Belonging}

How does Charkaoui map the place of the detainees in relationship to the "imagined community" 65 of Canada? Although Charkaoui gestures towards the humanity and individuality of the security certificate detainees, the Court sees them as fundamentally alien to Canada. Not only do they not belong to the nation whose security is encompassed by the ubiquitous term "national security" - even worse, the detainees are deemed to threaten this, "our" security. They are positioned as clearly distinguishable from Canadian society, as irreducibly alien. The legal remedies suggested by the Court barely conceal this abyss.

Analyses of previous security certificate decisions have noted that the Federal Courts have relied on "profiles" of terrorists based on travel patterns and ideology. Once a person is matched with a "profile", they have little room for disputing their designation as dangerous to Canadian security. ${ }^{66}$ On a more funda-

63 Macklin, "The Heft of Citizenship," supra note 45 at 354.

64 Ibid.

65 Benedict Anderson, Imagined Communities: Reflections on the Origin and Spread of Nationalism (London and New York: Verso, 1983).

66 Sherene Razack, "Your client has a profile': Race and National Security in Canada after 9/11" 
mental level, the language of process, law, evidence and innocence obscures the nature of the accusations at the heart of the certificates: security certificates can be issued for people who are members of organizations that might engage in terrorism in the future ${ }^{67}$ Thus, the certificate is to a significant degree based on predictions of future conduct and on assessments of inner dispositions that might not have surfaced in material actions. But how is a person to prove that they will not engage in terrorism? Given the folk knowledge voiced in court rooms that terrorism is connected to certain Islamic fundamentalist ideologies that are acquired or nourished by visits to "the region", and that someone "hooked" on these ideologies will remain committed to them, ${ }^{68}$ it is illusionary to expect someone who fits the terrorist profile to be able to prove that they are not dangerous. The speculative questions about a person's likely future associations, actions, and commitments have to be assessed by the Federal Court with the low standard of "reasonable grounds to believe" that favours the government's characterization of the case. The setup of the security certificate process encourages the translation of societal threat perceptions into legal exclusion orders.

In contemporary nation-states, the "imagined community" of the nation usually extends only to fellow citizens or nationals. The shape of the Canadian imagined community, expressed and shaped through institutionalized policies of multiculturalism and bilingualism, is elusive and widely debated. ${ }^{69}$ What it means to be Canadian is rarely explicitly attributed to immutable characteristics such as ethnicity, common language or shared history. Canadian-ness is most often described in terms of commonality in beliefs (in diversity, tolerance and liberalism) underlined by the assumption of (at least) residency and family ties in Canada. These beliefs, in turn, are more readily attributed to some demographic groups and more easily disputed for other groups. The culturally dominant or "original citizens" $"$ who derive their citizenship from ancestry and membership in a major cultural and language group have a firmer social standing than those who are relative "newcomers" and members of minority language and cultural groups. The Canadian National Security Policy, for example, begins by defining Canadian-ness by the moral (as opposed to legal or geographic) boundaries of the country. The "Canadian" of the National Security Policy is defined not by citizenship but through reference to Canadian values:

Canadians stand together in reaffirming that the use of violence to pursue political, religious or ideological goals is an affront to our values... No one better appreciates the need

(2007) 40 Studies in Law, Politics and Society 3 at 22-23 [Razack, "Your client has a profile"].

67 Immigration and Refugee Protection Act (2002) s. 34 (1)(f)

68 See Razack, "Your client has a profile" supra note 66 at 33-36.

69 See Rhoda Howard-Hassmann, "Canadian as an Ethnic Category: Implications for Multiculturalism and National Unity” (1999) 25(4) Can. Pub. Pol'y 523; and the rejoinder: Yasmeen Abu-Laban and Daiva Stasiulis, "Constructing 'Ethnic Canadians': The Implications for Public Policy and Inclusive Citizenship” (2000) 26 Can. Pub. Pol'y 477.

70 Sherene Razack, "Imperilled Muslim Women, Dangerous Muslim Men and Civilised Europeans: Legal and Social Responses to Forced Marriages” (2004) 12 Fem. Legal Stud. 129 at 145 [Razack, "Imperilled Muslim Women”]. 
to protect our society than those who chose this country as a place to build a better life or who fled the consequences of instability and intolerance in other parts of the world..$^{71}$

Some immigrants, and in particularly those who "chose" Canada for themselves, are readily embraced in the Canadian demos. Yet, "somewhere between the people who 'chose' Canada and the homogenous 'Canadians' opposed to violence, is the insertion of some non-Canadian 'other' (in a legal or national sense)." 72 The "foreignness" of those whose alleged values do not fit the National Security Policy's vision of Canadian-ness is not a given fact. ${ }^{73}$ Rather, it is established through this policy and other government pronouncements. Foreignness, as Bonnie Honig puts it, is "a symbolic marker that the nation attaches to the people we want to disavow, deport, or detain because we experience them as a threat." 74 It is therefore not reducible to the lack of formal citizenship. In the context of terrorism threats, foreignness becomes an attribute of the threat as well as of persons associated with the threat.

In Charkaoui, the detainees' foreignness is presumed and affirmed from the opening paragraph on. The judgment situates itself by describing "a tension that lies at the heart of modern democratic governance":

One of the most fundamental responsibilities of a government is to ensure the security of its citizens. This may require it to act on information that it cannot disclose and to detain people who threaten national security. Yet in a constitutional democracy, governments must act accountably and in conformity with the Constitution and the rights and liberties it guarantees. ${ }^{75}$

The government's mandate is to ensure the security of "its citizens" and to "detain people who threaten national security." These two groups presumably do not overlap: people who threaten national security are not part of the nation to be secured. The "citizens" are different from the "people who threaten national security" whom the government "may" be required to detain. "People who threaten national security" are implicitly associated with foreignness through contrasting them with "citizens". In framing the case as a balancing act between liberty and security, the Court slides towards balancing the citizens' security against the liberty (and security) of the detainees ("people who threaten national

71 “Securing an Open Society: Canada’s National Security Policy" (2004), online: Privy Council Office <www.pco-bcp.gc.ca/docs/InformationResources/Publications/NatSecurnat/natsecurnat_e.pdf> (date accessed: 31 August 2007).

72 Colleen Bell, "Biopolitical Strategies of Security: Considerations on Canada's New National Security Policy" (2005) YCISS Working Paper, Number 34, online: York University <www.yorku. $\mathrm{ca} /$ yciss/publications/documents/WP34-Bell.pdf> (date accessed: 19 September 2007) at 9.

73 See Bonnie Honig, "A Legacy of Xenophobia" (2002-2003) 27(6) Boston Review, online: Boston Review <http://bostonreview.net/BR27.6/honig.html> (date accessed: 19 September 2007)

74 Ibid [Honig, "Legacy of Xenophobia"].

75 Charkaoui, supra note 2 at para. 1, emphases added. 
security"), keeping the desires and interests of these two groups strictly separated. Charkaoui does not contemplate, for example, that people who appear suspect share everyone else's vulnerability to acts of violence; or that "citizens" as well as non-citizens might see their personal security threatened by anti-terrorism policies. Such considerations could have helped to blur the line between the stipulated interests of the citizens and the "others".

Charkaoui discusses the liberty and security interests of the detainees separately from national security. The detainees' security concerns receive attention because they evoke the case of Maher Arar, a Canadian wrongly accused of terrorism and 'rendered' to Syria by U.S. authorities with the complicity of Canadian authorities. The Court recognizes the "potential consequences of deportation combined with allegations of terrorism." ${ }^{\prime 6}$ The listed negative consequences of being labelled a terrorist in a security certificate procedure are all produced by courts or government institutions. The certificate process might "lead to removal from Canada, to a place where his or her life or freedom would be threatened," lead to the more general "accusation that one is a terrorist, which could cause irreparable harm to the individual," especially in the case of being deported to one's home country. Finally, a security certificate deprives a person of the protection from deportation to torture. ${ }^{77}$ The Court's answer to these grave threats to the detainees' well-being is to mandate a more thorough review process. This process aims to decrease the likelihood of falsely labelling people as terrorists, but would not change the situation of someone rightfully found to be a security risk: they could still be sent "to a place where his or her life or freedom would be threatened." In this case, rights and protections are scaled according to a person's asserted risk to national security.

In mandating a more thorough and searching review of the security certificates, the Court places much rhetorical weight on the judges' unease with the deficient current process. Judges who were involved in the security certificate process complained that the introduction of evidence unavailable to the detainee skewed the adversarial process to a degree that they felt "a little bit like a fig leaf." 78 In describing the deficiencies of the process, the court relies on the image of the judge who tries to "engage in a searching review" 79 of the record but might nevertheless miss relevant facts that would have emerged in a more open setting and therefore fail in the judicial aspiration to do justice. The casualty of justice is not described from the detainees' point of view, but from the perspective of the judges who "have worked assiduously to overcome the difficulties inherent in the role the IRPA has assigned to them." ${ }^{80}$ We see heroic judges trying to save the rule of law rather than the rights of the detainees as such:

The fairness of the IRPA procedure rests entirely on the shoulders of the designated judge. Those shoulders cannot

76 Ibid. at para. 26.

77 Ibid. at para. 14.

78 Ibid. at para. 50.

79 Ibid. at para. 39.

80 Ibid. at para. 51. 
by themselves bear the heavy burden of assuring, in fact and appearance, that the decision on the reasonableness of the certificate is impartial, is based on a full view of the facts and law, and reflects the named person's knowledge of the case to meet. The judge, working under the constraints imposed by the IRPA, simply cannot fill the vacuum left by the removal of the traditional guarantees of a fair hearing. ${ }^{81}$

In this account, the humanity, compassion and suffering of the judges - arising from the imperfections of the process - are afforded more visibility than the rights violations, despair and uncertainty suffered by the detainees. The Court's rhetoric suggests that the procedure needs to be revamped primarily because the judges are unable to fulfil their role of delivering justice, and only secondarily because the resulting decisions violate the detainees' Charter rights. The Court's proposals for remedies reflect this priority: The Court recommends, among other options, the British special advocate system that grants a lawyer with security clearance access to the privileged documents. ${ }^{82}$ This system stands good chances of being implemented by Parliament, and it stands equally good chances of being challenged as procedurally insufficient and unconstitutional by human rights and legal advocacy organizations. ${ }^{83}$ In its original British form, the special advocate is not allowed to consult with the detainee after seeing the evidence. As a result, the detainee does not know the case to respond to, and the special advocate knows the government information but has incomplete access to the detainee's knowledge about the events alleged in the government's dossier. These imperfections, however, apparently do not matter for the purpose of deciding Charkaoui: the Court acknowledges that the proposed system "may not be perfect from the named person's perspective," ${ }^{4}$ but Parliament has the ultimate say in these matters and is "not required to use the perfect, or least restrictive, alternative" to the current process. ${ }^{85}$ The alternative process to be drawn up by Parliament might ease the burden of judgment on the shoulders of the judges without necessarily satisfying the interests of the detainees.

The Court's discussion of additional procedural safeguards decentres the detainees' rights and focuses on the self-perception of the judicial system as a guar-

81 Ibid. at para. 63.

82 Ibid. at para. 83-84.

83 In committee hearings, the Canadian Muslim Lawyers Association, the International Civil Liberties Monitoring Group, the Canadian Bar Association, The Federation of Law Society of Canada, and the Barreau du Québec have indicated that they consider the proposed bill unconstitutional. See Standing Committee on Public Safety and National Security, $39^{\text {th }}$ Parliament, $2^{\text {nd }}$ session, hearings 005, 006 (29 November 2007). In addition, Amnesty International and Human Rights Watch have indicated their concerns, see Amnesty International, "Proposed Security Certificate Legislation Fails to Address Human Rights Shortcomings" (25 October 2007), AMR 20/C29/2007; Human Rights Watch, "Canada: Parliament Should Amend Bill on Special Advocates (Letter to Members of Parliament)" (19 November 2007), online: Human Rights Watch < http://hrw.org/english/docs/2007/11/28/canada17435.htm> (date accessed: 3 February 2008)

84 Charkaoui, supra note 2 at para. 86.

85 Ibid. at para. 85. 
antor of impartiality and the rule of law. Adding procedural safeguards does not guarantee a better rights protection for the detainees for at least two reasons. First, the additional procedural mechanisms may simply be insufficient to create a fair process; they might add up to no more than a "thin veneer of legality" ${ }^{66}$ barely concealing the executive-dominated character of the security certificate process. Second, even a thicker set of procedural protections might turn out to be a veneer masking the logical near-impossibility of disproving "reasonable suspicion" of one's dangerousness ${ }^{87}$ - especially if dangerousness is culturally coded to coincide with the religious and ethnic identities that one is seen to inhabit. In this case, the process satisfies society's self-perception as committed to the rule of law without addressing the underlying exclusions that make some people easy targets for security certificates and rightlessness.

\section{B. Citizens, Residents, Foreign Nationals: Formal Citizenship}

Charkaoui engages with the formal meaning of citizenship by affirming that non-citizens suspected of being threats to national security are subject to a legal framework that citizens are never subject to: immigration law. By insisting that Charkaoui is an immigration matter, the Court evades arguments about the unequal treatment of citizens and non-citizens in terrorism-related matters. In addition, the Court asks Parliament to devise a new security certificate procedure. Yet democratic institutions are often complicit in establishing different sets of rights for citizens and non-citizens because only citizens' interests are systematically (though imperfectly) represented in such bodies.

Charkaoui highlights the distinction between citizens and non-citizens by disallowing comparisons between the treatment of citizen terrorism suspects and the non-citizen security certificate detainees. The treatment of the non-citizen terrorism suspects raises the question of discrimination since Canadian citizens, irrespective of their dangerousness or intention to engage in terrorism, cannot be detained unless as part of criminal proceedings against them. Discrimination, however, presumes that two groups of persons who share relevant characteristics are treated unequally on the basis of irrelevant traits. The Court found that the security certificate process does not constitute discrimination because the mobility and residence rights of s. 6 of the Charter "specifically allow... for differential treatment of citizens and non-citizens in deportation matters: only citizens are accorded the right to enter, remain in and leave Canada." 88 The discrimination framework is unavailable as long as the case is treated as a deportation matter. The Court, relying on the Suresh exception that renders deportation never completely impossible, found that "the record on which we must rely does not establish that the detentions at issue have become unhinged from the state's purpose of deportation." ${ }^{89}$ Indeed, the availability of an ongoing "effective review process that permits the judge to consider all matters relevant to the detention" ensures

86 Re $M B$, supra note 15 at para. 103.

87 See Colleen Bell, "Subject to Exception: Security Certificates, National Security and Canada's Role in the "War on Terror"” (2006) 21 C.J.L.S. 63 at 70.

88 Charkaoui, supra note 2 at para. 129.

89 Ibid. at para. 131. 
that detention will continue only as long as it is connected to deportation. ${ }^{90}$ The procedural justice of ongoing review brings the detention closer to the principles of the rule of law and thereby normalizes it. ${ }^{91}$ Yet it silences the underlying questions about the nature and effects of the detention that depend on the substantive rightlessness of the circumscribed group of non-citizens.

The Court raises two allegedly hypothetical constellations in which the security certificate detention scheme might be discriminatory: "[f]irst, detention may become indefinite as deportation is put off or becomes impossible, for example because there is no country to which the person can be deported." 92 This situation, however, is already present: the five men have been held for prolonged periods of time. In the case of Mahmoud Jaballah, deportation to Egypt was specifically prohibited by a Federal Court. It is not clear, then, how his continued detention and supervised release are meaningfully connected to the attempt to deport him, let alone deport him speedily. The indefinite character of this detention and surveillance is not seen by the courts.

The logic of Charkaoui hinges on the distinction between, on the one hand, "lengthy and indeterminate" detention, which is conceded for the cases at hand, ${ }^{33}$ and, on the other hand, "indefinite detention", which is unconstitutional and allegedly not present in the current cases. Charkaoui affirms that "the IRPA ... does not authorize indefinite detention." 94 This statement is only plausible if "indefinite" is read to mean "endless", not if it means "lasting for an unknown or unstated length of time." The latter, however, is the Oxford English Dictionary's definition of "indefinite." 95 If the court had taken this definition of the term as its point of departure, it could have conceded that the combination of immigration legislation, administrative practice, and the protection against torture have created a constellation of indefinite immigration detention in Canada. By using a particular understanding of "indefinite" and insisting on the theoretical possibility of deportation even in the absence of strong evidence of governmental will or feasibility, Charkaoui upholds the fiction that security certificate detention is "lengthy" 96 but not "indefinite." These fine distinctions were lost on some commentators: a Globe \& Mail editorial summarized Charkaoui as ruling that "the indefinite jailing of non-citizens suspected of being terrorists is legitimate, as long as their detention is subject to meaningful and regular review." ${ }^{7}$ This is decidedly not what the Court intended to say, but the editorial might unwittingly have provided a perceptive account of the decision's effects.

The Court envisioned a second case in which, potentially, the detention would be unconstitutional: "the government could conceivably use the IRPA not for

90 Ibid.

91 See Dauvergne, "Security and Migration" supra note 7 at 534.

92 Charkaoui, supra note 2 at para. 130.

93 Ibid. at para. 105.

94 Ibid. at para. 127.

95 Online: Oxford English Dictionary <www.askoxford.com/concise_oed/indefinite?view=uk> (date accessed: 3 September 2007).

96 Charkaoui, supra note 2 at para. 98.

97 “The court reconciles liberty and security," Editorial, Globe \& Mail (24 February 2007) A18. 
the purpose of deportation, but to detain the person on security grounds." 98 This scenario can also be seen as a description of the current situation. After all, security and immigration have become intertwined as policy matters in the post-9/11 period. The Court started the Charkaoui judgment with a meditation on the tension between security and liberty, not a discussion of immigration law. The deportations that are ostensibly sought are not very likely to materialize. Ultimately, none of the persons named by a security certificate who fit the "profile" of a transnational Islamic terrorist have been deported after $9 / 11$. Detention on security grounds is at least a convenient side effect, if not the intended goal of the current administrative practice of issuing security certificates.

The Court's insistence that IRPA does not allow indefinite detention helps it to distinguish the Canadian cases from the British Belmarsh ${ }^{99}$ case that spells out a different understanding of the meaning and privileges of formal citizenship. Initially, the British post-9/11 detention scheme resembled the Canadian security certificates: upon certification, non-citizen terrorism suspects could be held pending deportation. Some of the detainees held in the Belmarsh prison turned out to be non-deportable because British jurisprudence incorporates the strict prohibition on deportation to torture developed by the European Court of $\mathrm{Hu}-$ man Rights in Chahal. ${ }^{100}$ They complained that they were discriminated against on grounds of nationality and immigration status: terrorism suspects who are UK nationals would either be free or subject to criminal proceedings, and deportable non-citizens could leave or would be deported. The Law Lords scrutinized the detention scheme more critically than the Canadian Supreme Court did in Charkaoui. The Lords followed the appellants' suggestion of comparing the treatment of terrorism suspects who are UK citizens and non-citizens. They consequently refused "to accept the correctness of the Secretary of State's choice of immigration control as a means to address the Al-Qaeda security problem, when the correctness of that choice is the issue to be resolved." 101 The Lords raised a number of pragmatic questions about the appropriateness of immigration measures to address terrorism threats: the provisions are not narrowly targeted at persons who support violence; ${ }^{102}$ and offering "a suspected international terrorist" to leave the UK to "perhaps a country as close as France" would be "hard to reconcile with a belief in his capacity to inflict serious injury to the people and interests of this country." ${ }^{103}$ In addition, the threat posed by UK citizen terrorism suspects is not addressed. In short, the provisions attacked in the Belmarsh case encompass persons who pose no actual threat, leave out others who would be threats, and provide a remedy that is strikingly ill-suited to the problem that should be addressed.

The House of Lords did not examine the detention scheme as an immigration matter: on the one hand, deportation was concededly impossible in the

98 Charkaoui, supra note 2 at para. 130.

99 Secretary of State, supra note 4.

100 Chahal, supra note 29.

101 Secretary of State, supra note 4 at para. 53.

102 Ibid. at para. 34.

103 Ibid. at para. 33. 
cases at hand. And on the other hand, the Lords did not identify terrorism as a problem exclusively attached to non-citizens. Evidence before the Court suggested that almost $30 \%$ of the suspects detained under the Terrorism Act were British citizens. ${ }^{104}$ The London Subway bombings of July 2005, six months after the Belmarsh decision was handed down, were committed by British citizens. ${ }^{105}$ The bombings reinforced the prevalent majority mistrust of immigrants and Muslims. For British courts and society, terrorism does not necessarily come from abroad, but from formal citizens who nevertheless lack crucial markers of "Britishness." This logic is not less exclusionary than the reasoning behind Charkaoui, but it draws the line elsewhere. ${ }^{106}$ The House of Lords approached the case as a security matter that the government chose to address through immigration law. The Lords found that "the appellants were treated differently from both suspected international terrorists who were not UK nationals and could be removed and also from international terrorists who were UK nationals and could not be removed." 107 Their treatment constitutes discrimination on the basis of nationality and immigration status, prohibited under Art. 14 of the European Convention on Human Rights.

There are two reasons why the Canadian Supreme Court in Charkaoui (as well as a Federal Court in Almrei, ${ }^{108}$ decided in 2005) could have relied on the standards developed in the Belmarsh case and yet have not found the Canadian security certificate scheme discriminatory. ${ }^{109}$ First, the Canadian legal constellation since Suresh makes it possible to claim a connection between detention and deportation. The detention thus appears lengthy but not “indefinite." In Almrei, decided in February 2005, a Federal Court reasoned: "In the House of Lords' decision, the legal impossibility of deporting to torture the persons arrested made the detention indefinite. In our jurisdiction, at this moment, deportation to torture remains a possibility and, therefore, each case will have to be assessed on its own merits." 110 In addition, terrorism is perceived as an exclusively foreign problem that is accordingly rationally addressed through immigration law: "There is no evidence, as there was in the English case, of a sizeable number of Canadian nationals being suspected of international terrorism whose detention would be required and yet not pursued and effected." 111 While the Almrei Court refused to compare non-citizen and citizen terrorism suspects because the latter category seemed empty, the Supreme Court in Charkaoui retreated to the more formal position that citizens and non-citizens cannot be compared in deportation matters because they have legitimately varying mobility rights.

104 Ibid. at para. 32.

105 Paul Majendie, "Minister says immigrants must 'earn citizenship"” Reuters UK (5 June 2007), online: Reuters UK <http://uk.reuters.com/article/domesticNews/idUKL0524542720070605> (accessed 14 September 2007).

106 See Dauvergne, "Security and Migration" supra note 7 at 536.

107 Secretary of State, supra note 4 at para. 51.

108 Almrei v. Canada (Minister of Citizenship and Immigration), [2005] F.C.J. No. 213; 2005 FCA 54 [Almrei].

109 See Dauvergne, "Security and Migration", supra note 7 at 539.

110 Almrei, supra note 108 at para. 127.

$111 \mathrm{Ibid}$. at para. 129. 
The Almrei position of seeing Canadians as categorically non-dangerous had become unsustainable since the eighteen suspects arrested in summer 2006 for involvement in a plot to bomb targets in Ontario including Parliament Hill were all Canadian citizens. ${ }^{112}$ In response to the arrests, a representative of the CSIS assured the public that "this operation in no way reflects negatively on any specific community or ethnocultural group in Canada," but his broader message questioned the separation between citizens and non-citizen terrorism suspects: "Terrorism is a dangerous ideology, and a global phenomenon. As yesterday's arrests demonstrate, Canada is not immune from this ideology." 113 Yet even if Canadian citizenship is not seen to rule out a person's involvement in terrorism, it still insulates them from some of the most repressive tools in the government's arsenal of anti-terrorism policies.

While Canadian anti-terrorism policies rely on a sharp distinction between holders of Canadian passports and everyone else, the British policies de-emphasize formal citizenship in favour of substantive citizenship. The Belmarsh decision that struck down the detention scheme based on immigration law was soon followed by a scheme of "control orders" that subject persons, deemed threats to British security, to conditions including house arrest, surrender of identification documents and passports, prohibitions on entering or leaving certain areas, and prohibitions on arranged meetings and unsupervised communication, to be specified by the imposing authority. ${ }^{114}$ These orders can, and have been, issued against both citizens and non-citizens. They are valid for one year, are renewable, and can only be issued if criminal prosecutions are not feasible. Courts have found some particularly restrictive control orders in violation of human rights, but a stream of jurisprudence has stabilized and normalized the practice of control orders and heightened surveillance against groups of people who have been determined to be dangerous but who cannot be prosecuted. ${ }^{115}$ Although the control orders do not discriminate between citizens and non-citizens, they continue to target persons who are perceived as foreign through their ties to Islamic groups. Here, new imaginaries of citizenship and foreignness are mobilized to draw a different line between those whose security is to be protected and those who pose security risks. The line no longer follows formal citizenship, and immigration law therefore becomes a useless tool for marking it. ${ }^{116}$ Yet the underlying logic is no less exclusionary.

Some Canadian commentators praised the Charkaoui's reliance on formal citizenship with a side glance at the Belmarsh decision and its effects. An editorial in the Globe \& Mail, for example, points to the negative example of

112 "In depth: Toronto bomb plot: Homegrown extremism" CBC News (14 July 2006), online: CBC News in Depth <www.cbc.ca/news/background/toronto-bomb-plot/homegrown-extremism.html> (date accessed: 19 September 2007) [“Toronto bomb plot"].

113 Ibid.

114 See Ip, “Comparative Perspectives," supra note 3; Re $M B$, supra note 15.

115 See Re MB, supra note 15; Secretary of State for the Home Department v. MB, [2006] EWCA Civ 1140; Secretary of State for the Home Department v. JJ and others, [2006] EWCA Civ 1141, Secretary of State for the Home Department v. E and another, [2007] EWCA Civ 459, AL v. Secretary of State for the Home Department, [2007] EWCH (Admin) 1970.

116 See Dauvergne, "Security and Migration" supra note 7 at 543. 
"the absurd ruling in 2004 that [Britain] was discriminating against foreigners because only they, and not citizens, could be detained without charges as part of an attempt to deport suspected terrorists" that led to "the horrible result" of "the creation of a draconian system under which anyone in Britain can be subject to house arrest without criminal charges being brought." 117 The Canadian courts and media largely take formal citizenship to be a meaningful criterion for delineating the scope of anti-terrorism policies. This presumes that violence and dangerousness comes from abroad. British courts, in contrast, treat formal citizenship or the lack thereof as less salient. The citizenship-based detention scheme was replaced by a scheme that normalizes restrictions and surveillance against non-citizens, as well as citizens - but in practice only against those who are seen as adherents to "foreign" dangerous ideologies. Although anti-terrorism measures often target people, to paraphrase Bonnie Honig, "because they are foreign," "the deeper truth is that we almost always make foreign" those who will be subject to detention or house arrest. ${ }^{118}$ A difference in formal citizenship enables discriminatory treatment, but this treatment is ultimately rooted in perceptions of foreignness.

The Canadian Supreme Court's second engagement with formal citizenship is contained in its formulation of the remedy. The Court refuses to spell out an appropriate set of rights for the detainees. Instead, it suspends the validity of its own judgment for one year and allows parliament to devise a new procedure. Yet parliaments are not safe places for the rights of non-citizens. The democratic process permits but does not require attention to the claims of non-citizens. They are not allowed to vote, and are therefore not represented by those who are elected. Democratic self-governance is only possible within "a circumscribed demos which acts to govern itself." ${ }^{119}$ These boundaries mark the scope of democratic citizenship and enfranchisement, but not necessarily the scope of the effects of the laws produced by the citizenry. The citizenry faces few disincentives against the implementation of policies that place unusual burdens on non-citizens. In the "war on terror," democratic electorates approve of measures against non-citizens that they would not tolerate if they could be applied to citizenspeople like themselves. The tendency of shoring up "our" (perceived) security through sacrificing "their" liberties ${ }^{120}$ is a product of a democratic system that places some checks on burdening minorities but far fewer checks on burdening non-members who are present in the polity. Given the Court's strong emphasis on the distinction between citizens and non-citizens, there is little reason to assume that a new process designed by the citizens' representatives will offer noncitizen terrorism suspects more than the minimum procedural rights required in Charkaoui.

117 "The court reconciles liberty and security," Editorial, Globe \& Mail (24 February 2007).

118 Honig, "Legacy of Xenophobia," supra note 73.

119 Benhabib, The Rights of Others, supra note 11 at 19, emphasis in the original.

120 David Cole, "Their Liberties, Our Security: Democracy and Double Standards" (2002-2003) 27(6) Boston Review, online: Boston Review <http://bostonreview.net/BR27.6/cole.html> (date accessed: 19 September 2007). 


\section{Fictions of Home and Agency: Imagining Supplementary Sources of Rights}

The reasoning of Charkaoui internalizes, rather than challenges, the vulnerability and rightlessness of the detainees. Through a conjunction of argumentative moves, the detention appears lengthy but not indefinite, subject to the rule of law, and not discriminatory. There is one more layer of citizenship and rightlessness that is exploited in the security certificate scheme: the quality of membership and rights claims in other jurisdictions. These claims could encompass international human rights with direct validity as well as citizenship rights in another state that lead to some forms of protection or at least the possibility of returning 'home'. The Supreme Court did not use international human rights as a binding source of law in either Suresh or Charkaoui. In contrast, the Belmarsh case was decided on the basis of the European Convention on Human Rights and binding precedents from the European Court of Human Rights. For the detainees in Canada, the only rights that could be claimed would need to be found in the Canadian Charter. The Charter, in turn, allows the balancing of individual rights against the needs of "a free and democratic society" (s. 1) such as concerns put forward under the label of national security. Human rights had very limited traction in these Supreme Court cases concerning the treatment of non-citizens, and it is far from certain that they would have made a difference in this case.

The detainees' countries of citizenship - Egypt, Morocco, Syria, and Algeria - all have records of using torture to extract confessions, especially from persons suspected of engaging in terrorism. Citizenship in any of these countries ceases to be a privilege for someone who is accused of being a terrorist and threatened with being sent 'home'. Deportation is a mechanism designed to restore nation-state based order of things in a transnational world of migrating subjects. Yet the cases of the detainees show that such an order can only be imagined; its imposition on the messy world of migration and security would only be possible at a heavy price. For example, Mahmoud Jaballah is surely wanted "at home" in Egypt - but he is wanted on an Interpol arrest warrant. Like dual citizens who find that their "lingering nationality" of the country of their birth puts them in a category of suspect populations, ${ }^{121}$ the security certificate detainees may be "subjected to the full punitive force" 122 of their unwanted nationality through deportation or the continued threat thereof. They might well prefer to be formally stateless than citizens of the countries to which they are currently attached. Their citizenships at once make them candidates for deportation - for they have a "home" to be returned to - and subject them to the threat of deportation to torture. The specific vulnerabilities of the security certificate detainees result from the particular constellation of citizenships that they carry with them. The Canadian state occupies two distinct roles in relationship to the detainees: On the one hand, it aspires to protect Canadian society from the detainees - hence the detention with the view to deportation. On the other hand, the state aims, at least tentatively, for the protection of the detainees from the threat of torture

121 Stasiulis \& Ross, "Flexible Sovereignty," supra note 45 at 343.

122 Ibid. 
abroad - hence the hesitation to deport them. In an exercise of "flexible sovereignty," ${ }^{123}$ the ambiguity that results from the tension between the dual mandates of protection enables the government to continue the detentions in order to protect both Canadian society (from the detainees) and the detainees (from the risk of torture).

Charkaoui acknowledges that detention with a view to deportation is a fictional construction in the cases of the five detainees: "voluntary departure may be impossible. A person named in a certificate of inadmissibility may have nowhere to go. Other countries may assume such a person to be a terrorist and are likely to refuse entry, or the person may fear torture on his or her return." ${ }^{124}$ In this admission, Charkaoui differs from prior Federal Court decisions that invested the detainees' with fictional agency to alter their fate. In Almrei, for example, the Federal Court squarely blames the detainee for the length of the detention that he is complaining about: "Mr. Almrei was to be and would have been removed were it not for the stay of removal that he sought and obtained." ${ }^{25}$ The detainees' legal fight against the threat of deportation is turned against them in the context of adjudicating the reasonableness of the prolonged detention. In addition, the Federal Court insisted that Almrei could still use the option of voluntary departure: "Mr. Almrei could have put an end to his detention if he had shown a willingness to leave the country. Most of his family, including his parents, live in Saudi Arabia. He has a sister living in Lebanon. He travelled freely to Pakistan, Afghanistan, Jordan, and other countries..." 126 The Almrei Court paints the image of a person who chooses the temporary inconvenience of detention in order to maximize his benefits, knowingly foregoing other available options. The Charkaoui decision is closer to recognizing that for some detainees, all available options are unsustainable. Their agency is reduced to fighting deportation, which they know they must avoid at all costs. For them, continued detention is the only alternative to the incalculable ills of deportation. Detention is simultaneously a relief from deportation and the substance of the complaints. Charkaoui left the Damocles' sword of deportation established by Suresh in place while addressing the justifiability of detention. In the cases of detainees who fear torture in their 'home countries,' detention and the threat of deportation are intertwining and mutually supporting threats: without the goal of deportation, detention would be illegal, according to Charkaoui. The decision does not see - or else exploits knowingly - the fact that some people experience forms of rightlessness that reduces their agency to fighting the two predicaments that the Canadian government wants them to choose between. The people who have been determined not to belong to Canada might in fact have "no place on earth" where they "could go without the severest restrictions, no country where they could be assimilated" 127 - their ultimate homelessness ${ }^{128}$ makes them vulnerable everywhere.

123 Ibid.

124 Charkaoui, supra note 2 at para. 99.

125 Almrei, supra note 108 at para. 128.

126 Ibid. at para. 101.

127 Arendt, Origins of Totalitarianism, supra note 8 at 293.

128 See Bauman, "Strangers," supra note 6 at 10. 


\section{CONCLUSION}

The Charkaoui ruling is an attempt to assimilate anti-terrorism policies to the rule of law. Yet the decision exploits rather than acknowledges the vulnerabilities of the people for whom being subject to security certificates means indefinite detention. The treatment of the non-citizens who are subject to security certificates does not hinge on their guilt or innocence as established in legal proceedings. Instead, security certificates are based on assessments of dangerousness. Dangerousness, in turn, is established on the basis of untested evidence and assumptions about future behaviour and associations. Persons who are subject to security certificates are judged according to what they are alleged to be (dangerous or not), rather than according to what they did. Yet the security certificate process is often described in terms borrowed from criminal law in ways that suggest suspicions about specific individual culpability that are in fact absent in these cases. Even the criticism of "secret trials" fails to capture that the proceedings, however deficient they might be, do not adjudicate guilt or innocence and do not amount to trials at all. The conjunction of rightlessness and the irrelevance of legal innocence in this context leads us back to consider Arendt's observation on the treatment of stateless people in interwar Europe: "Jurists are so used to thinking of law in terms of punishment, which indeed always deprives us of certain rights, that they may find it even more difficult than the layman to recognize that the deprivation of legality, i.e. of all rights, no longer has a connection with specific crimes." ${ }^{29}$ The aspiration to being "judged by one's actions and opinions," 130 in turn, can only be fulfilled if one belongs to a political community that recognizes one's distinctiveness and humanity, Arendt concluded. Security certificates do not adjudicate guilt or innocence in relationship to specific crimes, but a person's abstract dangerousness based on their "profile."

Security certificates exploit the rightlessness of some non-citizens by subjecting them to a process in which not their actions and opinions but their physical appearance, place of birth, and formal citizenship determine their fate. The Security Certificate Five are non-citizens of Canada who share additional vulnerabilities: they are perceived as alien and threatening to the national community, and their citizenships in Algeria, Morocco, Syria and Egypt operate as further liabilities rather than supplementary sources of rights. The Supreme Court's response to the detainees' claims adopted the language of constitutional rights rather than human rights. It addressed some concerns but upheld the fundamental distinction between citizens and non-citizens in the context of anti-terrorism policies.

Since the detainees' particular form of rightlessness results from a combination of their lack of formal citizenship, lack of effective belonging and the quality of their citizenships elsewhere, attempts to include them (and others) within the framework of ordinary legality need to pay attention to the intersecting sources of rightlessness. A proposal to follow the Law Lords' reasoning that citizens and non-citizens cannot be treated differently in anti-terrorism policies, for example,

129 Arendt, Origins of Totalitarianism, supra note 8 at 293.

$130 \mathrm{Ibid}$. at 296-297. 
should take into account that the Belmarsh decision led to legislation that allows house arrest and extensive surveillance of citizens and non-citizens who are seen as foreign and threatening to national security. This alternative route of normalized surveillance is no less exclusionary than the attempt to secure security on the backs of non-citizens. In the end, foreignness is not a natural attribute but a product of decisions about the shape of the nation whose security is to be protected; it is "not exhausted nor even finally defined by working papers, skin color, ethnicity, or citizenship. Indeed, it is not an empirical line at all; it is a symbolic one, used for political purposes." 131 As a result, the lines of foreignness drawn in national security policies and public rhetoric need to be challenged, not just redrawn. Finally, the threat of deportation despite the risk of torture holds the detainees hostage to their formal citizenships. The Suresh exception that enables the continued detention fails to acknowledge that for some people who allegedly don't belong "here," there is no other place to go. Nurturing the mistaken and unethical hope of deporting all those who are deemed threats to Canadian security fails to recognize that for a number of them, Canada is the only home they have. They, too, should have the right to have rights, meaning the right to belong "to a community willing and able to guarantee... rights." ${ }^{132}$ Respecting the detainees' right to have rights requires judging them by their actions. ${ }^{133}$ The current regime, in contrast, judges them by their asserted dangerousness - a dangerousness that is first constructed and then invoked in order to balance "their" rights against "our" security from the threat they are seen to pose.

131 Honig, "Legacy of Xenophobia," supra note 73.

132 Arendt, Origins of Totalitarianism, supra note 8 at 296-297.

133 Ibid. at 297. 